\title{
INFERENCE, PERCEPTION, AND RECOGNITION: KAŚMĪR ŚAIVISM AND THE PROBLEM OF OTHER MINDS
}

\author{
JOSHUA STOLL
}

\begin{abstract}
This paper will explore competing intuitions behind the problem of other minds. On the one hand, consciousness is strictly a self-manifest, first-person phenomenon: subjectivity is in each case one's own. On the other hand, it is obvious, on the basis of their behavioral activity, that others are conscious agents despite this coming across through objective determinations. The tension between these intuitions is what grounds the problem of other minds. Attempts to navigate this problem generally neglect one of these intuitions and so are inadequate accounts of intersubjectivity. As such, and given the paradox involved in accepting each intuition, I argue that we must look to traditions that are comfortable with paradox if we are to give an adequate account of intersubjectivity and the relationship between one's own and other minds. In particular, I point to the Kaśmìr Śaiva tradition, and specifically the work of Utpaladeva (ca. 900-950 CE) and Abhinavagupta (ca. 950-1025 CE), as an excellent resource for bringing together and holding in tension these paradoxical intuitions. For in this tradition, the very nature of reality is at once solipsistic and paradoxically revealed through a divine, intersubjective dialogue. As such, this tradition takes each intuition seriously despite the tension between them.
\end{abstract}

Keywords: Abhinavagupta, Kaśmīr Śaivism, other Minds, Pratyabhijñā, Utpaladeva

\section{INTRODUCTION}

We each have a special, intimate relationship with our own conscious experiences, a relationship that we simply cannot have with the experiences of others. As Giovanni Merlo recently put the point, though others may have fears and desires, and though their fears and desires may be more intense than mine, my fears and desires are fears and desires par excellence (Merlo 2016, 319). Caspar Hare points out that, all things being equal, we would prefer pain befall others rather than ourselves and that pleasure befall ourselves rather than others: preference is metaphysically grounded in an egocentric bias (Hare 2009, 35). And Benj Hellie suggests that consciousness doesn't manifest to us as a "constellation of points of phenomenal light," but is phenomenally embedded in a single perspective, in a particular place, engaged in a particular set and

STOLL, JOSHUA: Lecturer of Philosophy, the Humanities Division, University of Hawai'i at West O’ahu, USA. Email: js34@hawaii.edu 
series of experiences (Hellie 2013, 305). All these points suggest that subjective experience has a certain sense of centrality. It is in each case one's own alone; it is quintessentially in the first-person.

Given these considerations, we might ask: What is it about our experiences with others that makes it evident to us that others are not mere objects, that others are more like ourselves than like bookcases or rocks in that they "have experiences" in the sense discussed above, whereas the latter do not? How is it possible that we are manifestly subjects to each other if being a subject means being quintessentially selfmanifest? These questions bring up a problem that has been largely out of fashion in contemporary philosophical discourse: the problem of other minds. Despite the lack of interest in such a problem, there has been a great deal of focus in recent philosophy of mind, especially in the area of embodied cognition, on the accessibility of other minds through perception of others' bodily behavior. But these discussions often don't take the problem of other minds very seriously.

In what follows, we will start by exploring the problem of other minds, particularly in its epistemic formulation as a problem of how we can justify our apparent knowledge about the minds of others, and we will critically review some approaches to overcoming it. We will then investigate some ways of dissipating the problem, analyzing a few reasons why such a problem might be rejected as nonexistent. These reasons will be contested, and we will have occasion to reformulate the problem in broader terms. It will be further argued that it is incumbent upon any adequate account of intersubjective experience that such a problem be taken seriously. This means looking for an account of intersubjectivity that takes seriously the monadic distinctiveness of first-person subjectivity while maintaining the everyday, self-evident status of others as themselves conscious subjects. It will be suggested that the Pratyabhijñā or Recognition school of the Kaśmīr Śaiva tradition, and the work of Utpaladeva and Abhinavagupta in particular, offers us resources with which to articulate such a paradoxical picture.

\section{INFERENCE AND OVERCOMING THE PROBLEM OF OTHER MINDS}

Two different kinds of problems of other minds are often identified in the philosophical literature on other minds: the epistemological problem and the conceptual problem. Both problems rest on a fundamental asymmetry between oneself and others. We will open our inquiry by focusing on the epistemological problem and a certain approach to resolving it. Resolving a philosophical problem has often meant either dissipating or overcoming it. ${ }^{1}$ Dissipating a philosophical problem means denying that it exists or is uniquely relevant. This strategy simply does not take the problem seriously. Such a strategy will be considered more carefully in the next section. In this section, we will explore two attempts at overcoming the epistemological problem of other minds. Overcoming a philosophical problem means taking it a little more seriously than dissipating it: the existence of the problem is not

\footnotetext{
${ }^{1}$ The notions of 'overcoming' and 'dissipating' problems are borrowed from Quassim Cassam's terminology (Cassam 2007, 2).
} 
denied, but it is not considered genuinely problematic since it is not totally insuperable.

The epistemological problem of other minds and the possibility of epistemic solipsism are said to be the result of an asymmetry between one's direct perceptual knowledge of at least some of one's own experiences, and the indirect nature of one's knowledge of the minds of others (Hyslop 1995, 7). Since subjectivity is quintessentially one's own - that is, quintessentially 'mine' - I cannot be aware of your experiences in the distinctively first-person sense in which my experiences are perceptually self-manifest. And since your experiences are never self-manifest directly in my perception, I cannot be acquainted with your experience qua your experience. That is, I cannot be acquainted with what it is like for you to exist. As such, I am left with the possibility of epistemic solipsism: since your subjective world is hidden from me, as it were, there is no way for me to know whether you are having conscious experiences or what those experiences are about, not to mention what they are like.

Needless to say, these results have been found to be deeply unpalatable. Not only does it seem obvious that others have every bit of a living, vivid set and series of experiences as oneself does, but we all generally act accordingly and unquestioningly. Such a problem appears to be the sort of speculative rumination that can make philosophy seem silly. As such, the challenge cited above - the asymmetry in access to or manifestation of experience - is often not taken all that seriously when accounting for intersubjective experiences. Thus, as we will discuss further in the next section, either the asymmetry that grounds this problem is outright rejected or the problem is reduced to the problem of skepticism about the external world.

Those that do take this problem somewhat seriously often try to overcome it inferentially, and we ought to briefly pause to explore this option. In particular, the argument from analogy has been the dominant expression of the inference to other minds in the Western discourse. ${ }^{2}$ It is most well known in J.S. Mill's formulation (Mill 1979, 191), which runs roughly as follows:

1) I experience in myself certain feelings caused by sensory input and such feelings then cause me to perform actions.

2) I see similar actions performed by others when they are stimulated by similar sensory inputs as me, but I cannot perceive the inner feeling that causes their actions.

3) Since their behavior is so similar to mine under similar circumstances, I can, by analogy, infer that the actions of others are caused by similar inner feelings.

But the argument from analogy has been found to be wanting. One concern here has been that such an argument makes an unwarranted generalization on the basis of a

\footnotetext{
${ }^{2}$ As Alec Hyslop points out, even "scientific", abductive inferences must, in this case, appeal to the argument from analogy (Hyslop 1995, 31).
} 
single evidential case, namely the case of one's own experiences and their connection to one's behavior. But not only is this argued to be questionable inductive practice (Malcolm 1963, 131; Locke 1968, 49), its conclusion would also be meaningless. For if one understands what it means to be in a mental state solely on the basis of one's own, solitary experiences, it becomes a real question how such a conception of mind can be applied in the case of others (Malcom 1963, 136-137). ${ }^{3}$ A further complaint about such an argument, again suggesting that the inductive structure of it is problematic, is that the conclusion is logically impossible to check up on. As Don Locke puts it:

If, in an ordinary case, we are doubtful about whether an analogy holds we can check up and see whether it does, but the whole point about other minds is that we can never test whether the analogy does hold. (Locke 1968, 49-50)

Alec Hyslop has defended the argument from analogy against such charges. For example, he maintains that any inference that establishes knowledge of other minds, based as it must be on the causal connections between mind and body in one's own case, has a meager generalization base out of necessity (Hyslop 1995, 53). Moreover, he points out that we do in fact make other perfectly reasonable analogical inferences on the basis of single cases - for example, observing one egg breaking when dropped is enough to validate the analogical inference that the next egg will break if dropped as well (Hyslop 1995, 52). Finally, Hyslop defends the argument from analogy against the charge of uncheckability by noting that uncheckable analogical inferences are endemic to scientific practice, and so the fact that the conclusion cannot, in principle, be directly perceptually verified is irrelevant to the epistemic status of the conclusion (Hyslop 1995, 56-58).

One might, however, object to Hyslop's defense along the following lines. It relies on the principle that like causes have like effects, and that the only way an argument from analogy to other minds can work is if we apply this principle to the physical causes of mental phenomena (Hyslop 1995, 53). The contention is that since we can in principle know about the causal relationship between brain states and mental states in one's own case, this justifies the inference that someone else in the same brain state as oneself will be in the same mental state, even if the latter person's mental state cannot in principle be directly perceptually known by the one performing the inference. But it is unclear, given the correlational status of most evidence in cognitive neuroscience, whether such a broad causal claim tying brains states to mental states is warranted.

In addition, two minds cannot be similar in the sense in which, going back to Hyslop's example, two eggs are similar. For the accessibility to the correlation between physical states and mental states in one's own case is fundamentally different from the way that same correlation regarding someone else's mental and

\footnotetext{
${ }^{3}$ This is one way of formulating the conceptual problem of other minds, which will be discussed in more detail in the next section.
} 
physical states can be manifest to the inferrer. As we will see when we discuss the conceptual problem of other minds in the next section, we are aware of such correlations in the first-person case interoceptively while we can only ever be aware of such correlations with respect to others exteroceptively. But with regard to the two eggs, the correlation between dropping and breaking is only ever apprehended exteroceptively. So, the argument from analogy doesn't fit the pattern of a quasiscientific inference that Hyslop compares it to. Moreover, describing our basic knowledge of other minds on analogy with scientific practices of inductive and abductive reasoning grossly mischaracterizes the interactive cognitive practices of intersubjectivity.

Appealing to a similar principle of like causes producing like effects, but focusing on mental causes of physical phenomena, the great Buddhist philosopher Dharmakīrti, in his Proof of Other Psychophysical Streams (Santānāntarasiddhi), gives us an alternative argument to other minds. Under the assumption that all actions are caused by intentions to act, the argument infers the presence of unexperienced intentions as causal antecedents of objectively manifest actions: "The representations, in which the external marks of our own mind appear to us, are perceived by us subjectively. Therefore, the ones perceived objectively must have another cause" (Dharmakīti 1969, 66). We can flesh out the structure of this inference, aptly referred to as the argument from remainder by Jeremy Henkel (Henkel 2012, 71), roughly as follows:

1) Whenever there is an objective manifestation of my actions, there is a subjective manifestation of my intention to act as causing the objective manifestation, like when my desire to speak gives rise to a speech-act.

2) When there is the objective manifestation of speech from another body, no corresponding subjective manifestation of an intention to speak is experienced.

3) But, given the first premise, actions are universally concomitant with intentions.

4) Therefore, other streams of subjectivity (santānantāra) cause actions that are grasped objectively but not subjectively.

However, such an argument is question begging, for it presumes the very thing it sets out to prove: that there are other subjects of experience. In the words of Abhinavagupta, one of the principal voices of the Kaśmīr Śaiva tradition to which we will have occasion to refer later, "The experience 'this man speaks' depends upon establishing the existence of another subject and the existence of the latter depends upon the former" (Abhinavagupta 1998, 62). If I am to infer that another person has the first-person, subjective awareness of intending to speak on the basis of hearing their speech, I cannot presume that what I am experiencing is someone else speaking. That is, I can't already take their action to manifest in such a way as to suggest mental capacity; I can't take what I hear to be another person's speech. For it is precisely the presence of such mental capacity that is the object of the inference. But when another 
speaks, even when we hear garbled words, we still hear speech, and thus we always already take the speaker to be manifesting mental capacity.

Inferential approaches to overcoming the epistemological problem of other minds are thus problematic. For they require taking seriously the asymmetry between the directly perceptual self-manifestation of at least some of one's own experiences and the merely indirect manifestation of signs pointing to the inner subjective states of others. But in doing so, such approaches tend to mischaracterize the cognitive relationship between self and other by not taking seriously enough the readily exteroceptively perceptual character of the conscious agency of others. They also tend to run into logical problems with the structure of their arguments. However, it has been suggested that what is perhaps most questionable about such approaches is precisely that they take the problem seriously at all. This is the attitude of those who approach this epistemic formulation of the problem with the intention of dissipating it. Such a view essentially argues that there is no problem to be overcome because the minds of others are expressed in their behavior, which is amenable to direct perception. It is to such a perspective that we now turn.

\section{PERCEPTION AND DISSIPATING THE PROBLEM OF OTHER MINDS}

Dissipating the problem of other minds has taken on one of at least two forms. One approach has been to reduce the epistemological formulation of the problem to the conceptual problem of other minds, and then claiming that a resolution to the latter dissolves the former. Another approach to dissipating the problem, both in its epistemological and conceptual formulations, is by emphasizing the role that behavior and situated context play in the perceptual accessibility of the minds of others. Let us start by considering the first approach mentioned above: reducing the epistemological problem to the conceptual problem, and then attempting to resolve the latter.

In effect, the conceptual problem of other minds is the problem of whether we can coherently think of the subjective experience of others, of what it is like to be them. Two kinds of considerations are often behind such a concern. On the one hand, whether it makes sense to generalize mental concepts can be put in question. This issue is brought to light in Ratnakīrti's Refutation of Other Psychophysical Streams (Santānātaradūṣaña). In this response to his predecessor, Dharmakīrti, Ratnakīrti argues that the very idea of another stream of subjectivity (santānāntara) is incoherent because there is no way to establish a difference between two streams of consciousness without reducing the difference between another stream and one's own to a conscious event in one's own stream of awareness:

But there is no apparent difference [between two streams of consciousness]. For if a difference were to be apparent, there would also be the indisputable (durapahnava) appearance [in one stream] of the boundary of another stream (parasantāna) to which [that first stream] is related. (Ratnakīrti 1975, 247)

\footnotetext{
${ }^{4}$ na cāsau bhedah pratibhāse | bhedapratibhāse hi upagamyamāne tadavadhibhūtasyāpi parasantānasya pratibhāso durapahnavah syāt $\|$
} 
Conscious events are, so to speak, self-contained, and so the very idea of another series of conscious events would require a manifest difference within a single stream of conscious events between one's own series and another series of conscious events. But then another series of conscious events would have to be present to one's own series of conscious events, making the other series no different from one's own. As such, there can be no apparent difference between two sets of conscious events and so the idea of a stream of conscious events is applicable in only one case.

Moreover, we seem to apply mental concepts on the basis of fundamentally different criteria in first-person and third-person instances. In the former instance, we apply mental concepts to ourselves on the basis of reflection or introspection. But we apply mental concepts in the latter instance on the basis of the observation of behavior. As such, the question arises as to whether we are dealing with two different sets of mental concepts. For, as Donald Davidson puts it, "If two concepts regularly depend for their application on different criteria or ranges of support, they must be different concepts" (Davidson 1987, 16).

It has been supposed that resolving such conceptual problems would leave no grounds for the epistemological problem, that the former is logically prior to the latter. For once we account for how the same kinds of concepts can be applied generally across different streams of subjectivity, so the thought goes, we have already accounted for our epistemic access to the first-person experiences of others. This is most clearly the case in what has become the dominant approach to this problem: emphasizing the role of perceptually accessible behavioral criteria for the application of mental concepts across first-and-third-person instances.

We find, for example in the work of Bill Brewer (Brewer 2017) and Hanna Pickard (Pickard 2003), an emphasis on the role emotion plays in unifying mental concepts across first-person and third-person applications. Emotions can play this role because, it is argued, emotions are subjective experiences the content of which essentially refers to behavioral displays, to bodily actions. Thus, the concept of 'fear' is unified through its being perceptually apparent in both a subjective and objective mode simultaneously: to be afraid means to, for example, tremble in fear, which has both a subjective feel to it and an objective manifestation that is apparent to others. If it is possible to know whether someone else is afraid, it is because we must already be cognizant of this connection between the subjective and objective aspects of fearconsciousness in our own case.

Similarly, Quassim Cassam argues that in order to see whether someone else is angry, we must be perceptually aware that they are in the same state oneself is in when oneself is angry (Cassam 2007, 179). For if they lacked the relevant behavioral capacities or corporeal characteristics - the same capacities and characteristics that are relevant to my experience and expression of anger - it wouldn't make sense to say that we can see whether others are angry. Thus, it is claimed that by a sort of perceptual identification with the embodied actions of others, mental concepts are unified across first-and-third-person applications despite their apparent asymmetry. And, given the perceptual accessibility of embodied action, the epistemological problem is thereby dissipated. In the words of Anita Avramides, "Appealing to an 
essentially intersubjective notion like behavior would lead us to see that a solution to the conceptual problem of other minds would leave no room for an epistemological problem" (Avramides 2001, 271).

However, these appeals to perceptual identification with the embodied actions of others only pushes the problem to the register of the body. This challenge is similar to the one that was posed earlier to Hyslop's principle that like physical causes have like mental effects. As Joel Smith points out, there is still a fundamental asymmetry in the first-person manifestation of embodied action, which is grasped interoceptively, and the third-person manifestation of embodied action, which is grasped exteroceptively. As Smith puts it, these appeals have not "shown how there can be a single concept of perceptually presented bodily actions that can be applied in both first-and-third personal cases" (Smith 2010, 210). Anil Gomes, in his criticisms directed at Cassam's appeal to perceived identity, makes a similar point when he says that, for such an appeal to work, "I have to see myself as a subject. And visual perception simply doesn't present the subject in this way" (Gomes 2009, 226).

Thus, appealing to perceived identity and embodied action doesn't resolve the conceptual problem, and so such an approach seems to leave the epistemological problem intact - at least to the extent that the latter rests on the former. But it is perhaps worth asking whether we should take the conceptual problem to be logically prior to the epistemological problem. Indeed, not everyone sees what is especially problematic about the conceptual problem of other minds, independent of the epistemological formulation (Hyslop 1995, 9). For in order to have a general concept of something, we presumably must have some background set of knowledge that contextualizes the general significance of the concept and its applicability. And the kind of background knowledge that is required to have a general concept of mind is precisely what is put in question by the epistemological problem of other minds.

These problems therefore seem to be more interdependent than they are often taken to be. Both put into question the cognizability of others' subjective experiences given the irrevocably self-manifest ownness of experience. They are two sides of the same coin. We will thus treat the problems together as the problem of how we can make sense of intersubjective experience given the following conflicting intuitions: that experience quintessentially manifests itself subjectively as one's own in the firstperson; and that others nonetheless make their subjectivity readily apparent through objectively manifest behavioral activity.

Let us, then, look at appeals to the perceptual accessibility of others' experiences through behavioral displays as a way of dissipating the problematic asymmetry in manifestation in its own right, regardless of how we think of the relation between conceptual and epistemological formulations of this asymmetry. As alluded to in the previous section, there are two ways in which this perceptual approach has attempted to dissipate the apparent problem: by rejecting the uniqueness of the problem, thus making it superfluous; or by rejecting the asymmetry wholesale, thus denying that there is a problem at all. Let us start with the former approach.

In the mid-90s, Jerry Fodor declared that "It's gotten harder to believe that there is a special problem about the knowledge of other minds" (Fodor 1994, 292). The 
reason is because such a problem is thought to be redundant. For it is thought to provide no special puzzle for the philosopher beyond the generally skeptical problem of the external world. As Fred Dretske argues, this is due to the fact that, if our ordinary claims to know that others are in some mental state because we observe their behavior are to have merit, then our knowledge of other minds and our knowledge of other bodies must come through the same medium: perception (Dretske 1973, 35-36). Thus, if there is a problem about knowing other minds, it would be indistinguishable from a problem about knowing other bodies. But that is just the generally skeptical problem of the external world. So, the problem of other minds is not especially problematic. Dretske gives us an argument from redundancy that runs roughly as follows:

1) Either other minds are directly perceivable or not.

2) If they are, then there is no special problem of explaining how knowledge of other minds is possible: we just see other bodies as enlivened with psychologically pregnant meaning.

3) If, however, other minds are not directly perceivable, then the problem is no different from global skepticism about the external world.

4) Either way solipsism offers no special headache for philosophers.

5) Therefore, there is no special problem of other minds.

But such an argument is deeply misleading. We can see this by imagining a Cartesian-like scenario of global skepticism. Suppose that your whole life has been experienced in a computer simulation run by Descartes' demon. Then, the demon informs you of your situation and, furthermore, that he is shutting down the program. Suppose that you survive the shutdown: you wake up the next day, and everything is just like it was before. You carry on your life with the knowledge that, up until now, it has been a simulation.

But what, then, are you to make of all the people you met throughout your life? Wouldn't you still need clarification as to the status of your friends and family? Were all these people simulated people, or were they really there being deceived along with you? Were they simulated others before the demon shut down the simulation, but now ordinary thinking, feeling people? How could you tell? This thought experiment suggests a disanalogy with how we perceive ordinary objects, and thus an issue distinct from skepticism about the external world. For we can have no doubt about the reality of the external world, and still be in doubt as to the reality of other people's experiences.

A related approach to dissipating the problem would be not just to deny that it is uniquely relevant, but that there is any problem at all. That is, such an approach would simply deny that there is any problem in accessing the mental states of others or that the self-manifest ownness of subjective experience makes intersubjective understanding problematic. For other minds just are perceptually accessible to us through our observations of and interactions with them. This is effectively the approach found in a recent trend at the intersection of philosophy of mind, 
phenomenology, and cognitive science called enactivism which emphasizes the situated, embodied, and interactive aspects of intersubjective experience and understanding. Enactivists therefore object to any characterization of other minds as, in the words of Shaun Gallagher, "hidden away and therefore not accessible to perception" (Gallagher 2008, 536).

The mental life of others, according to enactivist contentions, is made transparent to direct perception through our interactive behavioral comportment, through our participating with each other to make sense of a shared world. As Hanne De Jaegher rightly notes, "Social interaction is not derivative, but constitutive of the process of social understanding and also of direct social perception" (De Jaegher 2009, 538). In ordinary intersubjective experience, we do not have to perform the mental gymnastics involved in inferential procedures. We are directly acquainted, through interaction, with others; we are accessible to each other due to shared embodied architectures and historically situated social practices. As such, the direct perceptual manifestation of the embodied action of others alone does not help explain intersubjective cognition; it requires reference to perceptually available background contexts as well. Thus, Gallagher avers:

Practically speaking, direct perception, etc. delivers what I need to interact with others most of the time. In the broad range of normal circumstances there is already so much available in the person's movements, gestures, facial expressions, and so on, as well as in the pragmatic context, that I can grasp everything I need for understanding in what is perceptually available. (Gallagher 2008, 540)

But such an outright rejection of what Nivedita Gangopadhyay and Katsunori Miyahara call the problem of access, and therefore a rejection of the asymmetry in the manifestation of one's own and other's mental lives, is questionable. As Gangopadhyay and Miyahara argue, insofar as our perceptions of others do not fully manifest their first-person subjectivity, the direct social perception approaches favored by enactivists cannot simply brush off the accessibility problem. For although we get some semblance of knowledge regarding the minds of others through perception, we certainly do not have access to every detail of their subjectivity, to their experience qua their experience. There is still an asymmetry in the mode of manifestation, and thus the accessibility problem still looms over these proposals:

Even if some aspects of the other's mind are immediately given in his or her expressive behavior, as long as the mental state is not fully manifest to us, we still need to go beyond the immediate experience to gain a better understanding of the other. Accordingly, one could remove the access problem from the explananda of a theory of social cognition only if one assumes that mental states are given in expressive behavior in a way such that not a single significant aspect of mental states qua mental states are hidden from our view in the experience of expressive behavior. This assumption, however, contradicts a fundamental intuition about other minds: the intuition that other minds are characterized by an 'otherness' partly because they are always transcendent of what we experience. (Gangopadhyay and Miyahara 2015, 701) 


\section{THE PARADOX OF INTERSUBJECTIVITY}

To review, then, the problem of other minds that we are engaging with is to be understood broadly as the problem of how to make sense of intersubjective experience given that there is a fundamental asymmetry between the subjective manifestation of experience in one's own case and the readily apparent objective manifestation of subjectivity that is not one's own, that is, the presence of other subjects alongside oneself. Attempts at resolving this problem, both in its epistemic and conceptual formulations, have themselves turned out to be questionable. For they each attempt to account for intersubjectivity without taking seriously one of the two paradoxically interconnected intuitions that makes intersubjectivity both problematic and possible.

On the one hand, then, we have the intuition that there is something fundamentally distinctive about consciousness: experience manifests itself in the firstperson, in such a way as to be in each case simply one's own, that is, subjective. First-person awareness is thus continuously self-established in the very manifestations of experience; it is that unbroken transparency of awareness itself through which the multiplicity of objects in the world are manifest. It is thus not itself an object, but the constant manifestation of objects: it renders what it is like to exist amidst the variety of objects in the world. As such, there can simply be no firstperson awareness of someone else's first-person subjectivity, nor can I genuinely access your mental state (or any mental state, for that matter) as an object of knowledge without derogating from its status as mental, as knowing-thinking-feeling activity. Moreover, my will is in an important respect autonomous, independent of the whims of others. So, your experience, your agency, your consciousness - in short, what it is like for you to exist - is thus fundamentally outside of my purview, for my world is centered around myself, my experience, my actions, my consciousness what it is like for me to exist. Let's call this the centering intuition.

On the other hand, despite this distinctiveness of first-person subjectivity and the resultant sense in which other minds cannot be self-manifest, the first-person subjectivity of others is also intuitively apparent in our interactions with them. Though their attempt to dissipate the problematic asymmetry seems to simply neglect the centering intuition, enactivists are right to emphasize the role of socially situated and embodied interaction in constituting a certain transparency in intersubjective cognition despite the opacity that results from the centering intuition. For others can often be "open books"; we may know someone who "wears their heart on their sleeve." As some authors have noted (Dretske 1973; Perkins 1966), if we commonly speak of our perceptions of others - what they think, feel, or want - it is because we sometimes directly perceive what they think, feel, or want in our interactions with them. Thus, the behavioral activity that others manifest in our interactions with them makes perceptually apparent in a quasi-objective manner the unified selfestablishment of the subjectivity of others in the diversity of their actions as we

participate in making sense of things together. In short, others tell us and show us 
what it is like to be in their position, though we can never grasp this in its fullness. ${ }^{5}$ Let's call this the decentering intuition.

These are powerful intuitions that ought to be taken seriously. For, there is no intersubjective experience without the tension between these two intuitions; together they constitute a basic description of what intersubjective experience is like. But they are also constitutive of the asymmetry that makes intersubjectivity philosophically problematic. The perils of dismissing either of them can be seen in the failures of attempts at resolving the problematic asymmetry in respect of the manifestation of subjectivity that results from these intuitions. In particular, the two common approaches to navigating this asymmetry that we've so far explored each neglect one of these intuitions, and thus fail to account for intersubjective experience. Overcoming the problem inferentially doesn't respect the intuition that the subjectivity of others can be made perceptually transparent through socially interactive behavior - the decentering intuition. But trying to dissipate the problem hasn't respected the intuition that subjectivity is uniquely centered on oneself, making the first-person subjectivity of others as it is subjectively manifest to them opaque to oneself - the centering intuition.

Taking the nature of intersubjective experience seriously means taking the problem of other minds, and thus the asymmetry of subjectivity grounded in the centering and decentering intuitions, seriously. But these intuitions are at odds: the centering intuition says that subjectivity is quintessentially in the first-person, so that the minds of others must be opaque to us; the decentering intuition says that the minds of others are nonetheless fundamentally transparent to us as their subjectivity can be exhibited in their objectively determinate actions. Accepting each intuition, as we must if we are to account for intersubjectivity, results in paradox.

What is meant here by saying that accepting each intuition results in paradox? To accept the centering intuition is to accept subjectivity as being plainly mine, that what it is like to exist is manifestly first-personal. Accepting the decentering intuition, however, means that such what-it-is-likeness manifests itself outside of the firstperson perspective, so that what is quintessentially first-personal and subjective is made, no less fundamentally, to be third-personal and objectively determined. Thus, the first-personal or subjective element, at the moment of intersubjective, secondpersonal experience, manifests itself as not itself, as existing in a third-personal or objective mode. Each subject, while remaining subject and therefore non-objective, is at one and the same time manifest as object, and therefore non-subjective.

The paradox here is due to the asymmetry in the manifestation of first-person subjectivity in the midst of intersubjective participation which, as Dan Zahavi puts it, is an "existential fact" (Zahavi 2014, 151). Despite being non-objective, first-person subjectivity, through second-person participation, is in fact objectively determined.

\footnotetext{
${ }^{5}$ And, it is worth noting, neither can they. To the extent that subjectivity, the "what it is like" to be in a situation, cannot be fully objectified, as we will see when we discuss Abhinavagupta's notion of the self-luminousness of cognition below, consciousness can never fully encapsulate itself in determinate cognitions. This accounts for the fact that self-knowledge is an achievement, and that we can often be wrong about what we think we know about ourselves.
} 
We can characterize this predicament, to use Shlomo Cohen's phrasing, as an existential paradox, a paradox with respect to what it is like to exist as a socially involved self-conscious subject. Accepting these two intuitions renders the intersubjective experience, and thus the subjectivity of those who participate in it, a "duality within unity" (Cohen 2014, 28) whereby "the subject assumes the character of an object" (Cohen 2014, 29). The freedom and spontaneity of subjectivity, of "what it is like to be", is thus made to be that for which there isn't anything it is like to be - an object - and yet in this being "made to be", it is evident that there, paradoxically, is something it is like to be such an object.

To clarify, one sense of a subject or subjectivity being "made to be" objectively determined is exhibited in Sartre's discussion of shame. Such an experience, like all experience, is quintessentially in the first-person, and therefore subjective: there is something it is like to be ashamed of oneself. Yet shame, for Sartre, is instigated through the a priori intersubjective structure of consciousness wherein one can feel looked at and objectified, wherein one has a sense of being made to be an object beyond one's discretion. It is, as Cohen puts it, "an experience of recognizing myself as other" (Cohen 2014, 29). Thus, one's sense of oneself is arrested in shame, one has the experience of being objectified, ossified, and thus made to be that which is not a subject, namely, an object for-others; it is "an implicit and non-thematized comprehension of being-able-to-be-an-object on the part of the subject for whom I am an object" (Sartre 1956, 385).

But this sense of subjectivity being "made to be" an object has not yet broached the peculiar nature of the paradox that attends accepting both the centering and decentering intuition. For what we have here is at best a paradox within the centering intuition alone: an "internal schism", as Cohen puts it (Cohen 2014, 32). Such an experience does not require an empirically present other to take hold. Indeed, for Sartre, an experience like shame, wherein one can feel looked at, defines the possibility of there being empirically present others. Thus, Sartre arguably wouldn't accept the paradox being suggested here since for him, others cannot at first be objects for oneself, and so the decentering intuition would have to be a "second moment in my relation" to others (Sartre 1956, 382) since it implies that the subjectivity of others is presented simultaneously as subject and in an objectively determinate manner.

What is being proposed here, then, is that in the first instance, intersubjective subjectivity involves the simultaneous objectification of all participants by way of and despite the subjectivity, the ownness, of each individual's conscious agency grounding their sense of what it is like to be. The paradox of intersubjectivity that arises in accepting both the centering and decentering intuitions implies that intersubjective experience is not in the first instance defined by an individual subject's sense that they can be objectified from the outside, thus signaling the existence of subjectivity outside of themselves. Rather it implies a single unified experience in the first-person, which is in each case one's own, across multiple individuals such that, aside from one's own case, first-personhood is rendered as firstpersonhood principally in the third-person. The first-person is therefore one who, in 
the existential facts of second-person interaction, while maintaining their own firstpersonhood, spontaneously and freely makes a third-person of themselves and finds the first-personhood of others solely in the autonomous objective determinations made by these others. To be a first-person who participates in second-person activity is to be one who participates in the willing of first-personhood into the third-person in all directions, ${ }^{6}$ and thus one who is made to understand subjectivity in objective terms. As Camus says, "To will is to stir up paradoxes" (Camus 25, 1975).

\section{RECOGNITION (PRATYABHIJÑ̄̄) AND TAKING THE ASYMMETRY SERIOUSLY}

It has been argued that two conflicting intuitions are responsible for the problem of other minds, but that denying either one results in an inadequate account of intersubjective subjectivity. Yet accommodating both, it was argued, results in paradox. For one intuition says that subjectivity, what it is like to exist, is manifestly first-personal. The other says that subjectivity can nonetheless be made manifest. The second-person encounter is where first-persons participate in making their "what it is like to exist" objectively manifest, so that I in my first-person subjectivity am made to be aware of your first-person subjectivity only through your spontaneous acts of objective self-determination. Subjectivity thereby gets defined in terms of what it is not, namely in objective terms. Simply put, when you do things, I recognize that the lights are on.

We cannot, then, escape the paradox of intersubjectivity if we are to understand what it is like to exist as a self-conscious social being in the midst of intersubjective participation. Thus, it would be helpful if we had some language and a conceptual apparatus comfortable with paradox to help us further articulate such an experience. It is at this point that we turn to the Kaśmīr Śaiva tradition, a collection of Indian philosophical and spiritual practices and ideas that centers on a conception of ultimate reality as the pure consciousness of the deity Siva, sometimes termed paramaśiva. A few words by way of general introduction will help us gather a basic sense of what is promising about this tradition's way of thinking for our purposes.

As noted, the ultimate nature of reality for Kaśmīr Śaivism, also sometimes called Trika Śaivism, is pure or supreme consciousness, paramaśiva. It is an absolute unity in which the awareness of all distinction is dissolved. However, this absolute conscious unity is not an inert witness to the unfolding of the universe, as in other Indian traditions such as Advaita Vedānta, and the manifest distinctions of the everyday world are not mere unreal appearances. Instead, paramaśiva actively churns out the universe, in accord with its own freedom (svantantra), by dividing itself. In doing so, it manifests the diverse totality of the cosmos by externalizing itself for itself yet remaining within itself. And indeed, the cosmos is simply the power of supreme consciousness to manifest itself as different from itself. Thus, as Gavin

\footnotetext{
${ }^{6}$ That is, not only does one objectify themselves in their action, and not only do others do the same, but - in keeping with the Sartrean insight - one objectifies the self-objectifications of others, and they do the same to oneself.
} 
Flood puts it, "The Trika conception of this absolute is inherently ambiguous" (Flood 1993, 32). In particular, while it is said to be one, it at the same time comprises two principles. And these principles can themselves be articulated in a couple of ways, for example personally as Śiva and his consort Śakti, or more impersonally as light (prakāśa) and reflection (vimarśa). ${ }^{7}$ These principles are in a perpetual and cosmically pervasive bipolar tension as "opposed but mutually attracting forces" (Flood 1993, 74).

Cosmologically, this unity actively differentiates itself into various levels of reality which are, despite being different, all identical. This is because each level is itself a manifestation ( $\bar{a} b h \bar{a} s a)$ of supreme consciousness. These manifestations are simply ways that paramaśiva wills itself to be. They therefore truly exist and aren't unreal according to the Trika tradition. ${ }^{8}$ As such, the different manifestations within each level of the cosmos are considered to be real, though limited forms of the ultimate reality, determined in their manifestation by the principles most explicitly operative at each level. Thus, absolute consciousness, while the unified basis for manifest diversity, is itself that manifest diversity. The relationship between the supreme consciousness and its manifestations is therefore one of both identity and difference (Flood 1993, 104). The Trika philosopher Kșemarāja thus tells us that Siva's absolute consciousness "both transcends the universe and is the universe" (Kșemarāja 1982, 54) and that although he is one, "he becomes of twofold form, threefold, fourfold, and of the nature of seven pentads" (Kșemarāja 1982, 63). In Flood's words, "The Śaiva cosmos is self-inclusive and differentiated at all levels" (Flood 1993, 55).

At the level of the sort of limited consciousness we humans experience, we forget, according to the Trika tradition, the true magnitude of what we are: the supreme, absolute consciousness of Śiva himself. Kaśmīr Śaiva soteriology thus tells us that, through ritual practice and philosophical argumentation - itself considered a form of ritual practice - a recognition (pratyabhijñ $\bar{a}$ ) of our unity in diversity with paramaśiva is necessary to achieve liberation (mokșa). Indeed, this relationship between limited self and the true Self, being one of identity in difference, is, as Bruno Nagel puts it, contradictory (Nagel 1995, 501) and so recognition (pratyabhijñ $\bar{a}$ ) is a spiritual achievement that reveals our full nature "in its true paradoxicality" (Nagel $1995,513)$. With such a paradoxical conception of subjectivity, and of reality as the free self-differentiation and self-limitation of the unitary, supreme, absolute

\footnotetext{
${ }^{7}$ We will give more substance to these pairs of notions shortly.

${ }^{8}$ The idea is essentially that insentient objects (jada), if they were not of such a nature as to be amenable to cognition, would never be manifest. And if they could never be manifest, they would be "as good as non-existent in themselves" (Abhinavagupta 1998, 15). But being manifest does not make them unreal or merely apparent, since the manifestation of the various objects of experience is generated by and identical with paramaśiva. Thus, Abhinavagupta says that "It is to be admitted that the multiplicity of the objects of the world is as it is determinately apprehended... substance, action, and relation which involve temporal and spatial order, are real; because every one of them shines in a separate determinate cognition" (Abhinavagupta 1998, 14).
} 
subjectivity, the Kaśmīr Śaiva tradition offers us tools to accommodate the paradox of intersubjective experience.

Now, it is worth noting that, when it comes to other minds, Trika philosophy "is not a philosophy of intersubjectivity in a strict sense" (Nagel 1995, 517). This is because even others, who are manifest as different for limited subjects such as we are, are at the same time ultimately identical with us. Yet given their comfort with a unified diversity of consciousness, with what we, following Shlomo Cohen, have called an existential paradox, we can turn to Trika philosophy, and the Recognition (pratyabhijña) school of Abhinavagupta and his predecessor, Utpaladeva, in particular to help us articulate a picture of intersubjectivity that accommodates the paradox that has been argued to be at the heart of the intersubjective experience of human persons. Indeed, Harvey Alper's description of the goal of Abhinavagupta's religio-philosophical work in particular is precisely what defines our present goal: "To encompass - without reconciling - contradictions, that is, to attempt to be faithful to the confusion of experience, to be consistent to inconsistency" (Alper 1979, 383). Similarly, we are looking "to be faithful to the confusion of experience" intersubjective experience specifically. And, as it turns out, Utpaladeva and Abhinavagupta have some insightful things to say on this topic that speak precisely to the intuitions behind the intersubjective problematic we've been exploring.

In the first instance, despite being solipsistic, ${ }^{9}$ the tradition is steeped in a kind of dialogical metaphysics grounded in its Āgamic revelations. As Sthaneswar Timalsina puts it, "The agency of Siva or Bhairava in the Âgamic paradigm is intersubjective and dialogical, and the collection of Ägamas... are revealed in dialogue with the supreme being" (Timalsina 7, 2014). In keeping with the solipsistic tendency of this form of non-dualism (advaita), these dialogues are all "essentially the self-revealing act of Śiva" (Timalsina 12, 2014). But in his self-revelation, Siva also externalizes himself as his consort and interlocutor, as the personification and manifestation of his power, Śakti, and the dialogue they proceed to engage in is itself both the materialization of the world and the Āgamic self-revelation (Timalsina 12, 2014).

This is perhaps most clearly seen in the The Tantra of the Supreme TripleGoddess (Parātrísikātantra) and Abhinavagupta's commentary on it, the Exposition (Vivarana). The Tantra is a dialogue wherein the goddess Śakti asks Śiva to teach her about the nature of the Absolute or Unsurpassable (anuttara), which is itself identical to Śiva's conscious agency (prakāśavimarśa). It begins with Śakti addressing Śiva with the following question:

The exalted goddess said (to Bhairava): 'O God, how does the unsurpassable divine Consciousness bring about immediately the achievement of the identity of the empirical I with the perfect I-consciousness of Śiva which comes about in this very physical body

\footnotetext{
9 "The light of consciousness, which is associated with another person at the empirical level, is nondifferent from the light of consciousness of the cognizing subject. The otherness is due to the limiting conditions of it... Therefore, all knowledge, whether it be in Sadāśiva or in a worm, is the knowledge of one knower" (Abhinavagupta 1998, 17).
} 
and by the mere knowledge of which one acquires sameness with the Universal Consciousness-power (khecarī)?' (Abhinavagupta 1988, 5-6)

Here, the phrase "O God" (deva) is in the vocative case (sambodhana). And Śiva's response too is in the vocative case: "Listen, O most illustrious one" (Abhinavagupta 1988, 65). As Abhinavagupta puts it, such phrasing has "a greater connotation than an ordinary noun," namely the identity of the addressee with the addressor (Abhinavagupta 1988, 55-56). That is, rather than picking out and referring to an individual, as an ordinary noun does, the vocative case transforms a name into an address that picks out and identifies with another individual as actively sharing or participating in the manifestation of the world. In asking Siva a question, in addressing him, Śakti is exhibiting her simple identity with him as a single continuous conscious agency - the Unsurpassable (anuttara) itself. Indeed, Abhinavagupta tells us that addressing (ammantrayante) someone is simply the sharing of a sense of self:

Ordinarily, the I (ahambhāva) of the other person is different from the 'I' of the person who is to address, but in the process of addressing, the addressor assimilates the delightful autonomy of the addressed characterized by I-feeling to his own, and considering it as identical with the uninterrupted delight of his own I-feeling, starts addressing him. (Abhinavagupta 1988, 70-71)

Thus, for this tradition, the foundation of reality as subjectivity in the form of Siva's conscious agency is identical to its manifestation out of a dialogue with Siva's externalized alter ego, Śakti. And Śakti represents Śiva's power (śakti) to participate in, and not merely witness, the manifestation of a world. In John Dupuche's apt words, "Since Śiva essentially involves Śakti and Śakti implies 'You' the 'I' essentially implies 'You'. The 'I-Thou'... is at the heart of all' (Dupuche 2001, 2).

The Kaśmīr Śaiva tradition thus builds intersubjectivity into the very fabric of reality, and indeed, more importantly for our purposes, into the structure of the paradigmatic conscious subject. For one of the main lessons we can glean from Abhinavagupta's comments in his Parātrīisikāvivarana, to borrow phrasing from Arindam Chakrabarti, is that the You is found to be that "in contrast and community with which the Self discovers its own playful knower-hood" (Chakrabarti 2016, 109). But how does this tradition's conception of intersubjective subjectivity help us with articulating the tension between the centering and decentering intuitions without simply collapsing the two or neglecting either one?

We can begin our considerations in this respect with the centering intuition. In the second verse of Utpaladeva's Verses on the Recognition of the Lord (Íśvarapratyabhijñākārikāa), echoing a famous passage from the Brihadāranyaka Upanișad, Utpala asks: "What intelligent being could ever deny or establish the cognizer and agent, the Self, Maheśvara, established from the beginning (ädisiddhe)" (Utpaladeva 1994, 85). Here, Utpaladeva points out that both denying and establishing the cognizer (jñatari) and agent (kartari) through argument is impossible without presupposing one's own always already established self-nature (svātmanyādisiddhe). In other words, trying to prove or disprove one's own existence 
both presuppose what is being proven or disproven, namely, a synthetically identified continuity of many actions and cognitions. ${ }^{10}$

Now, being "always already established" (ädisiddhe), the subject, which is no different from the continuity of subjectivity in this tradition, is self-established or self-luminous (svaprakāśa). Consciousness is therefore considered by Utpaladeva and Abhinavagupta to have the nature of light (prakāśasvabhāva), illuminating (prakāsate), and thus making possible the manifestation of, insentient objects (jada). Such a conception of subjectivity is therefore consistent with the centering intuition in the following respect: subjectivity, and the objects of subjective awareness qua objects of awareness, are simply self-established subjective facts that are at least in part constitutive of reality, of what there is (cf. Merlo 2016). As Abhinavagupta puts it in his Examination of the Verses on the Recognition of the Lord (İ́varapratyabhijñāvimarśinī),

If the self were not shining, the whole world would be nothing but a mass of darkness, or it would not be even that... If we deny self-shining nature to the subject, there remains no room for question and answer. (Abhinavagupta 1998, 16)

Indeed, being self-luminous (svaprakāśa), and thus at the very least, the phenomenological grounds for the objective manifestation of things, ${ }^{11}$ subjectivity, for this tradition, cannot be fully manifest as an object of any cognition: "One cognition is not to be made manifest by another. For, if one cognition were to shine in another, it would cease to be self-manifest" (Abhinavagupta 1998, 33). Since the nature of subjectivity is to be self-luminous (svaprakāśa), were it to be made manifest by another self-shining agency, it would not be self-luminous but merely, like an inert object (jada), something that is of the nature of light (prakāśasvabhāva) in the sense of illuminable, but dependent for its illumination, for its manifestation, on something that is self-luminous, something that is its own source of light.

This accounts for the centering intuition: the self-transparency of subjectivity in the first-person makes the subjectivity of others qua subjectivity opaque, that is, noncognizable. For, in the words of Isabelle Ratie in her comments on intersubjectivity in the Pratyabhijñā school of thought, "We cannot perceive these cognitions [of other subjects] as we can perceive a mere object in the world, precisely because cognitions are not objects to be passively manifested, but self-luminous entities" (Ratié 2007,

\footnotetext{
${ }^{10}$ It is worth noting that Utpaladeva is specifically showing that we cannot deny or establish the existence of the Self in the ultimate sense of Siva, and so this passage, like the rest of Utpaladeva's $k \bar{a} r i k \bar{a}$ s, has a religious and soteriological significance to it that we should not neglect. However, part of the point of his karrikās is to bring about the recognition (pratyabhijña) of an identity between one's limited self and the ultimate Self of Śiva. So whatever can be said of Siva-consciousness can be said, in a limited respect, of the everyday, bound, empirical subject.

${ }^{11}$ To be sure, the Kaśmīr Śaiva conception of the subject has it stand as more than merely a phenomenological ground for the awareness of objects: it is the ontological ground. Indeed, in an ultimate sense, the objects themselves and their manifestations, and thus the consciousness that makes their manifestation possible, are identical as they are made manifest by the active self-diversification of the unity of Śiva's consciousness.
} 
338). Subjectivity, according to Abhinavagupta and Utpaladeva, is not passively manifest to awareness in the manner of mere inert objects. Part of what it means for consciousness to be self-luminous is that it is autonomous or self-dependent (svatantra): it establishes itself in actively articulating itself, that is, in making objective determinations. Consciousness is thus principally not just self-luminous (svaprakāśa) but also reflective or articulate (vimarśa, literally: touching back on itself). For Kaśmīr Śaiva ontotheology, this means that Śiva does the impossible: he quasi-objectifies himself. That is, he freely limits himself by actively manifesting part of his consciousness in objective terms.

For our purposes, what is important is that the same conscious agency behind illuminating cognition also actively limits itself as it articulates and makes manifest its place in a world. The idea here is very similar to enactivist appeals to autonomous sense-making in accounting for cognition as an embodied phenomenon. As Evan Thompson and Mog Stapleton put it in their account of autonomous sense-making, "What makes living organisms cognitive beings is that they embody or realize a certain kind of autonomy - they are internally self-constructive in such a way as to regulate actively their interactions with their environments" (Thompson and Stapleton 2009 , 24). Thus, in a similar manner to Śiva's self-imposed contraction (samkocana) into a limited embodied subjectivity, enactivists account for cognition in active terms: as constructing, maintaining, and expressing - that is, making sense of - the unified identity of an individual through the self-limiting process of bringing about a multifarious environment of practical significance (Thompson and Stapleton 2009, 25).

Subjectivity therefore actively, and autonomously, brings its world to light. We can see, then, how the Trika tradition can help us account for the centering intuition. For their account of self-consciousness is that of a self-established and thus autonomous, non-objective basis for making objective determinations. That is, as with recent enactivist accounts of mind, cognition actively manifests a world for itself by making objective determinations of its own; it centers the diverse world of subjectively manifest objects around itself - indeed, it brings such a world about in its activity so that there is something it is like for it to exist. But unlike the tendency of enactivist accounts of intersubjectivity to shrug off the centering intuition, the Trika emphasis on the self-established, non-objective nature of subjective awareness allows us to preserve the idea that intersubjective experience is, like any experience, in each case mine - thus obscuring whatever awareness we can have of other minds qua subjectivity.

What about the decentering intuition, that despite the appeal of the centering intuition, other minds are readily apparent to perception through interaction? Utpaladeva helps us account for this aspect of intersubjective experience by appealing, as we have seen is common in contemporary discussions on other minds, to the role of perceptually available embodied action: "Knowledge is self-established (svatah siddham); action, when it manifests itself through a body, becomes cognizable also by others. Thanks to it, knowledge of others can be guessed" (Utpaladeva 1994, 87). As we've seen, under the Kaśmīr Śaiva conception of mind, 
subjectivity or consciousness is self-established in both a luminous (prakāśa) aspect and an actively self-articulated (vimarśa) aspect. When this active aspect is bound to the sort of bodily existence we experience, its self-establishedness becomes articulated through the diversity of bodily actions. Under these conditions, Utpala says, other minds "become cognizable also by others" (parairapyupalaksyeta) and "knowledge of others can be guessed" (anyajñānūhyate).

Here, we have Utpaladeva avoiding the use of standard inferential terms in Indian epistemology while describing the manner in which other minds manifest themselves to us through bodily action as being a matter of a "guess" ( $\bar{u}$ hyate). Abhinavagupta, in his Vimarśini, explains that Utpaladeva avoids using the terminology of valid inference in describing our cognition of others because "The power of knowledge is not an object of any means of right knowledge. Otherwise he would have used the word 'is inferred' (anumiyate)" (Abhinavagupta 1998, 17). This, again, is an expression of the inability of us to grasp other minds as we do mere objects of inference. But what about as objects of perception? Indeed, in Utpaladeva's Vrtti, his commentary on his Kärikās, he describes the reflective activity of consciousness (vimarśa) as becoming "directly perceptible in other subjects through the final stages of bodily movement" (Utpaladeva 1994, 87).

But we must be careful, for we cannot read Utpaladeva as suggesting that other minds can simply be perceived like other objects in the way that has been supposed, for example, by Dretske. For others actively manifest their subjectivity objectively while inert objects wait for our gaze, as it were. So, we can't simply be taking Utpaladeva to be saying that others and their mental states can be mere objects of perception, for cognitive activity manifests itself in the extremities of its embodiment and is therefore not a passive manifestation of simple objecthood.

However, Utpaladeva does make use of the terminology of perception. Abhinavagupta further explains this use of perceptual terminology and avoidance of standard inferential terminology in his Íśvarapratyabhijñāvivrtivimarśinī, a commentary on Utpala's autocommentary, as due to intersubjective experience involving, in part, sensory perception: "Here, in part, the senses are also put to work (indriyavyāpāranam), so a 'guess' implies being readily apparent to perception (sākșātkāra)" (Abhinavagupta 1938, 101). ${ }^{12}$ Thus, consistent with the decentering intuition, the subjectivity of others is readily apparent to sensory perception. But, in what sense can this be so if, at the same time, others cannot merely be objects of my awareness? What is it that is readily apparent to sensory perception if not an object of knowledge?

Focusing on Utpaladeva's suggestion that bodily movement is the end point or final stage (paryanta) of the continuous unfolding of conscious processes and cognitive activities can help us here. It implies an identity between consciousness and bodily activity. ${ }^{13}$ In the Pratyabhijñā system of the Kaśmīr Śaiva tradition, action is

\footnotetext{
12 atrāṃśe indriyavyāpāraṇamapi asti, tataśca sākṣātkāramupalakșyati ūhah \|

${ }^{13}$ Indeed, the multifarious cosmos actively manifested by yet identical with supreme consciousness (paramaśiva) is considered to be the latter's body in the Trika tradition (Flood 1993).
} 
not something distinct from knowledge, as if located in a body that is ontologically distinct from a mind. Action itself is not essentially different from knowledge, where the latter is the distinct causal antecedent of the former. Rather, it is an autonomous self-manifestation of the power of knowledge, the actualization of the capacity to know. Thus, as Ratié puts it, "We are aware of the existence of other subjects when we are aware of their actions for the simple reason that consciousness is, in its essence, action" (Ratié 2007, 347).

As such, when we perceive others in their actions, we therefore perceive - at least in part - their conscious agency itself, their presence as other subjects of a life. We get a snippet of what it is like for them to exist. What is thereby readily apparent is autonomous conscious agency manifesting itself in making its own objective determinations, that is, engaging in objective, determinate activity. And since this conscious agency is nothing distinct from the very bodily activity we perceive making objective determinations, the consciousness of others partially manifests itself in those very actions, but not as a causal antecedent distinct from and prior to those actions. Instead, others are self-established in their bodily activities, that is, in their self-objectifications, because their multifarious actions are just the surface features, so to speak, of a single unified consciousness.

Because of this quasi-objectification of conscious activity that holds diversity together in a self-established unity, Abhinavagupta suggests that there is indeed an inferential aspect to our perceptual awareness of others. But it is not a causal inference (käryahetu) since consciousness is not considered a causal antecedent to bodily activity. Instead, since what is apparent to perception just is the autonomous objectification of conscious activity, and since the subjective manifestation of that conscious activity cannot be entirely apparent to perception, a constitutive inference (svabhāvahetu) is involved in our encounters with other limited subjects:

Because action, being the tail end (pucchabhütā) of knowledge itself, and knowledge, being inseparable (aprthagbhütam) from the knowing subject, a difference is constructed [between knowledge and action] due to a difference in what is communicable (samvedyabhedāt kalpitabhedam) [by the action], so this is really a constitutive inference, not a causal inference. (Abhinavagupta 1938, 105-106) ${ }^{14}$

Being thusly identified with bodily activity but being only partly communicable through any finite set of bodily activities, the conscious agency of others is partly perceived and partly inferred. However, since others manifest themselves in their autonomous quasi-objectifications, they are never simply present as objects dependent on another source of light. Instead, others are self-luminous (svaprakāśa), making themselves readily apparent to one's own perception in their cognitive activity (vimarśa) as, like oneself, having their self-nature always already established (svātmanyādisiddhe). A 'guess' therefore consists in being ready to apprehend perceptually apparent autonomous activity as partly expressing, and therefore

\footnotetext{
${ }^{14}$ Yata eva jñānasvyaiva kriya pucchabhūtāa, jñānam ca pramāturaprthagbhūtaṃ, samvedyabhedātkalpitabhedam, tata eva svabhāvaheturayam vastutah, na kāryahetuh $\|$
} 
exhibiting identity with, a singular subjective experience that fundamentally manifests itself, shows a fragment of its existence, but is not quintessentially selfmanifest. Thus, the decentering intuition is respected, not just because others and their mental states are admitted as being readily apparent to perception, even if only partly, but because others are readily apparent in such a way as to not be ossified, as if they were merely inert objects subject to being passively illuminated by one's own conscious awareness. They are continuously, actively involved in transmogrifying their subjectivity into objective determinations.

It may be objected, at this point, that the Pratyabhijñā system falls into the sort of problems that embodied approaches to dissipating both the conceptual and epistemological problems of other minds run into. Recall that such approaches also argue for a kind of identity between subjective manifestations of mental events and objective, bodily manifestations of those same events. Quassim Cassam, for example, argues for a perceived identity between first-person applications of mental concepts and third-person applications of the same concepts: we can only see that others are, say, angry, if they exhibit appropriate behavior that we can perceptually identify as the sorts of behaviors we exhibit when we are angry. A similar idea, we saw, is put forth by both Bill Brewer and Hannah Pickard: since being angry implies both bodily manifestations like clenching fists as well as experiential manifestations like a sense of rage, anger is unified as a concept and perceptually accessible even when we are not the ones enraged. And we noted objections to such ideas raised by both Anil Gomes and Joel Smith to the effect that these positions leave some form of the conceptual problem of other minds intact at the level of the body since the subjective manifestations of such bodily activities are fundamentally different from the objective manifestations of those same activities. Isn't something similar going on with Abhinavagupta and Utpaladeva? Aren't they committing the same error as Cassam, Brewer, and Pickard?

It is worth noting first, in response to such a concern, that neither Utpaladeva nor Abhinavagupta are trying to resolve any problem of other minds such as we may conceive of it in contemporary analytic philosophy. They describe a phenomenology, ontology, and cosmology wherein the intuitions that have here been argued to ground the problem coexist in a paradoxical tension; there is no attempt to explain either aspect of intersubjective experience away in order to solve an intellectual puzzle. And our appeal to these thinkers was likewise not in order to resolve any such problem. The point of focusing on what these Pratyabhijñā philosophers have to say was to bring to light a way of thinking about intersubjective subjectivity that keeps the tension between the conflicting intuitions behind such problems intact. In discussing these ideas, we are looking to stay true, as noted above, to the confusion of experience. So, charging these thinkers, or our use of these thinkers, with not resolving either the conceptual or epistemological problems of other minds would be to strawman this discussion.

Moreover, the guess ( $\bar{u} h a)$ that Utpaladeva and Abhinavagupta allude to is not just a perceived identity between objectively determinate actions and subjectively manifest thoughts and feelings, though this is surely involved. That is to say, the 
epistemic state or event of guessing ( $\bar{u}$ hyate) is not just a positive perception, like the perception of objects around us. Rather, it is a limited form of the ultimate conscious state for these thinkers, namely, recognition (pratyabhijñ $\bar{a}$ ). Though recognition does, in part, imply a perceived identity of the sort criticized respectively by Gomes and Smith, its emphasis is on the removal of error and the remembrance of something already understood, namely one's paradoxical identity in difference with other subjects.

Thus, what is of importance in recognition (pratyabhijĩ $\bar{a}$ ), and thereby its limited form as a guess, is not so much the acquisition of a new positive bit of knowledge that since I can do what others do, I can identify mental states with bodily states across different ranges of evidence. Rather, recognition is the always already understood but endlessly obscured presence of subjectivity outside of the selfestablished limited subjective manifestations that are in each case one's own. I recognize in others my own continuing and active participation in the world-process because others actively address me, and I them, in a continuous unification of disparate elements that are always in tension. Through this recognitive act of address, we go about enacting our partially perceived, and completely befuddling, differential identities with each other as we participate with each other to make sense of the confusion of experience together.

\section{CONCLUSION}

The problem of other minds has not been taken very seriously by contemporary philosophers, resulting in distorted and inadequate accounts of intersubjective experience, knowledge, and cognition in general. It has been suggested here that taking the problem seriously requires acknowledging and accommodating opposing intuitions. On the one hand, there is the centering intuition which suggests that subjectivity, what it is like to exist, manifests in the first-person. Experience is centered, in each instance, on oneself. On the other hand, the decentering intuition says that others autonomously make manifest to us their subjective lives through selfobjectifying determinations. The paradox of intersubjectivity, which has been argued to define intersubjective subjectivity and ground the problems of other minds, is that what it is like to exist is self-manifest in the first-person, but that it nonetheless actively manifests itself in objective, third-person terms.

In order to accommodate these paradoxical intuitions while accounting for intersubjective experience, reference was made to the Pratyabhijñā system of Kaśmīr Śaivism, a philosophical and spiritual perspective that is comfortable with paradox. Though such intellectual puzzles are not of concern for the Pratyabhijñā thinkers, they provide helpful ways of thinking through and accounting for the sort of intuitions that generate the contemporary problem of other minds in analytic philosophy of mind while preserving the phenomenology of intersubjectivity provided by these intuitions. Their concept of recognition (pratyabhijñ $\bar{a}$ ) provides us with a way of expressing our paradox without resolving it. It allows us to say that the

first-person phenomenon of what it is like to exist can be recognized as actively 
occurring in third-person terms despite being a first-person phenomenon, especially in second-person participatory acts such as address (ämantrana). Thus, such an appeal was meant to account for and hold in tension these conflicting intuitions, rather than resolve the intellectual problems generated by them.

This tension is of paramount practical, and not merely theoretical importance. For it is arguably the tension between some such set of intuitions that accounts for the ethical and political tensions of everyday life. Here, the value-neutral intellectual problems transmogrify into the value-laden predicaments of socially, politically, and culturally conditioned lives. Trust, care, and sociopolitical autonomy are all conditioned by the existential fact of the asymmetry in manifestation of subjective experience. Fleshing out the intricacies of these value-laden notions and, moreover, living them, would thus require acknowledging and accommodating the paradoxical tension that manifests itself through intersubjective transactions. Thus, more than being an intellectual riddle that needs solving, problems of other minds are symptomatic of the impossibility yet necessity of navigating a human life. Intersubjectivity is therefore a living existential and axiological predicament, and not just a theoretical and conceptual problem to be resolved.

\section{ACKNOWLEDGEMENTS}

I would like to thank Arindam Chakrabarti for his continued encouragement and extensive feedback on several ideas presented in this paper. I would also like to thank Vrinda Dalmiya for encouraging me to pursue the employment of the Kaśmīr Śaiva tradition in thinking through the problem of other minds, as well as Ronald Bontekoe for challenging me to articulate reasons why this problem ought to be taken seriously. In addition, I am grateful for two anonymous reviewers whose comments were integral to the clarification and fuller articulation of key concepts in this paper.

\section{REFERENCES}

Abhinavagupta (1998), İ́svarapratyabhijñāvimarśin̄̄, trans. K. C. Pandey (Varanasi: Sampurnanand Sanskrit University).

Abhinavagupta (1988), Parātrīśikāvivaraṇa, trans. Jaideva Singh (Delhi: Motilal Banarsidass).

Abhinavagupta (1987), İśvarapratyabhijñāvivrtivimarśinī, ed. M.K. Shāstrī Volume I (Dehli: Akay Book Corporation).

Alper, Harvey (1979), "Śiva and the Ubiquity of Consciousness: The Spaciousness of an Artful Yogi", Journal of Indian Philosophy 7.4: 345-407.

Avramides, Anita (2001), Other Minds (New York: Routledge).

Brewer, Bill (2017), "Emotions and Other Minds", Peter Goldie (ed.), Understanding Emotions:Mind and Morals (New York: Routledge), 23-36.

Camus, Albert (1975), The Myth of Sisyphus (New York: Penguin Books).

Cassam, Quassim (2007), The Possibility of Knowledge (New York: Oxford University Press). 
Chakrabarti, Arindam (2016), "How Do We Read Other's Feelings? Strawson and Zhuangzi Speak to Dharmakīrti, Ratnakīti, and Abhinavagupta", Comparative Philosophy Without Borders, eds. Arindam Chakrabarti and Ralph Weber (New York: Bloomsbury Academic Publishing), 95-118.

Cohen, Shlomo (2014), "Human Being as Existential Paradox", Appraisal: A Journal of Constructive and Post-Critical Philosophy and Interdisciplinary Studies 10.1: 28-32.

Davidson, Donald (2001), "Knowing One's Own Mind", in his Subjective, Intersubjective, Objective: Philosophical Essays Volume 3 (New York: Oxford University Press), 15-38.

De Jaegher, Hanne (2009), "Social Understanding Through Direct Perception? Yes, by Interacting", Consciousness and Cognition 18.2: 535-42.

Dharmakīti (1969), "Santānāntarasiddhi with Vinītadeva's țîkā", in Debiprasad Chattopadhyaya (ed.), Papers of Th. Stcherbatsky Translated for the First Time into English, trans. Harish C. Gupta (Calcutta: Indian Studies Past and Present), 84-112.

Dretske, Fred (1973), "Perception and Other Minds", Nous 7.1: 34-44.

Dupuche, John (2001), "Person to Person: Vivarana of Abhinavagupta on Parātrimśikia Verses 3-4", Indo-Iranian Journal 44.1: 1-16.

Flood, Gavin (1993), Body and Cosmology in Kashmir Śaivism (San Francisco: Mellen Research UP).

Fodor, Jerry (1994), "Jerry A. Fodor", in Samuel Guttenplan (ed.), A Companion to the Philosophy of Mind (Oxford: Blackwell), 292-300.

Gallagher, Shaun (2008), "Direct Perception in the Intersubjective Context", Consciousness and Cognition 17.2: 535-43.

Gangopadhyay, Nivedita and Miyahara, Katsunori (2015), "Perception and the Problem of Access to Other's Minds", Philosophical Psychology 28.5: 695-714.

Gomes, Anil (2009), "Other Minds and Perceived Identity", Dialectica 63.2: 219-30.

Hare, Caspar (2009), On Myself and Other Less Important Subjects (Princeton: Princeton UP).

Hellie, Benj (2013), “Against Egalitarianism”, Analysis 73.2: 304-20.

Henkel, Jeremy (2012), "How to Avoid Solipsism While Remaining an Idealist: Lessons From Berkeley and Dharmakīrti", Comparative Philosophy 3.1: 58-73.

Hyslop, Alec (1995), Other Minds (Boston: Kluwer Academic Publishers).

Kṣemarāja (1982), Pratyabhijñāhṛdayam, trans. Jaideva Singh (Dehli: Motilal Banarsidass).

Locke, Don (1968), Myself and Other: A Study in Our Knowledge of Other Minds (New York: Oxford University Press).

Malcolm, Norman (1963), "Knowledge of Other Minds", Knowledge and Certainty (Englewood Cliffs, NJ: Prentice-Hall), 130-140.

Merlo, Giovanni (2016), "Subjectivism and the Mental”, Dialectica 70.3: 311-42.

Mill, John Stuart (1979), An Examination of Sir William Hamilton's Philosophy, J. M. Robson (ed.), The Collected Works of John Stuart Mill Volume IX (Toronto: University of Toronto Press).

Nagel, Bruno (1995), "Unit and Contradiction: Some Arguments in Utpaladeva and Abhinavagupta for the Evidence of Self as Siva”, Philosophy East \& West 45.4: 501-525.

Perkins, Moreland (1966), "Seeing and Hearing Emotions", Analysis 26 (6): 193-197.

Pickard, Hanna (2003), "Emotions and the Problem of Other Minds", in Anthony Hatzimoysis (ed.), Philosophy and the Emotions (New York: Cambridge University Press), 87-104.

Ratié, Isabelle (2007), "Otherness in the Pratyabhijñā Philosophy", Journal of Indian Philosophy 35.4: 313-70. 
Ratnakīrti (1975), "Santānātaradūṣaṇa”, Ratnakīrtinibandhāvali, ed. Anantalal Thakur (Patna: K.P. Jayaswal Research Institute), 145-149.

Sartre, Jean-Paul (1956), Being and Nothingness, trans. Hazel Barnes (New York: Washington Square Press).

Smith, Joel (2010), "The Conceptual Problem of Other Minds", Proceedings of the Aristotelian Society 110.2: 201-217.

Timalsina, Sthaneshwar (2014), “The Dialogical Manifestation of Reality in the Āgamas", Journal of Hindu Studies 7.1: 6-24.

Thompson, Evan, and Stapleton, Mog (2009), "Making Sense of Sense-Making: Reflections on Enactive and Extended Mind Theories", Topoi 28.1: 23-30.

Utpaladeva (1994), İśvarapratyabhijñākārikāa, tr. Raffael Torella (Rome: Istituto Italiano Per Il Medio Ed Estremo Oriente).

Zahavi, Dan (2014), Self and Other: Exploring Subjectivity, Empathy, and Shame (New York: Oxford University Press). 